\title{
New Orleans, Nodal Point of the French Atlantic
}

\author{
Bill Marshall \\ French Section \\ School of Modern Languages and Cultures \\ University of Glasgow \\ 16 University Gardens \\ Glasgow G12 8QL \\ b.marshall@french.arts.gla.ac.uk
}

keywords: New Orleans Atlantic race Saint-Domingue New France slavery American Civil War Degas

Abstract: This article argues for the importance of New Orleans within French and Francophone Studies, with a particular emphasis on a French Atlantic perspective. A historical overview discusses the role of New France, slavery, native Americans, Spain, immigration from Saint-Domingue, the Louisiana Purchase and the American Civil War in the formation of the city, and the rich and under-researched field of the city's nineteenth-century literary output in French is surveyed. Among the unique aspects of this history are the coherent African cultures exported to Louisiana due to the trafficking of slaves of mostly Bambara ethnicity, their crucial role in the material survival of the colony, and the large presence - from intermarriage, manumission under Spanish rule, and an influx following the Haitian revolution - of free people of colour who contributed to the formation of a Caribbean-type racial hierarchy that did not exist elsewhere in the United States. The article ends with an overview of French representations of the city, in particular A Cotton Office in New Orleans by Edgar Degas, and the city's place in world tourism, generating questions about the mobile and hybrid meanings attaching to 'Frenchness' in this context.

Résumé: L'article affirme l'importance de la Nouvelle-Orléans pour les études françaises et francophones en mettant l'accent sur une dimension 'atlantique' ou 'atlantiquefrançais'. Un tour d'horizon historique souligne les rôles de la Nouvelle France, de l'esclavage, des amérindiens, de l'Espagne, de l'immigration venant de Saint-Domingue, de la vente de la Louisiane et de la guerre de sécession dans la création de la ville, suivi d'un examen de la production littéraire francophone du dix-neuvième siècle, injustement passé sous silence de nos jours. Les réalités uniques de la Nouvelle-Orléans ont leur origine dans divers facteurs tels que le recrutement d'esclaves de l'ethnie Bambara, ce qui a produit une culture africaine cohérente dans le territoire qui a aidé la jeune colonie à survivre physiquement; et la présence importante - et inhabituelle dans la société américaine de l'époque - de gens libres de couleur à cause de la fréquence de mariages et d'accouplements mixtes, des possibilités d'affranchissement sous le régime espagnol, et de l'arrivée de réfugiés de la révolution haïtienne. Finalement, une discussion de représentations françaises de la ville, en particulier le tableau Bureau de coton à la Nouvvele Orléans, mais aussi la ville comme destination touristique, permet de soulever des questions concernant les significations mobiles et hybrides de 'la francité' dans le contexte atlantique. 
The destruction of New Orleans in August 2005 by Hurricane Katrina and by man-made policy failures focussed attention on the fragile heritage of a city unlike any other in the United States, as well as underlining the continued economic and institutional marginalisation of much of that country's population of African descent. Reconstruction has become a terrain of struggle between conflicting economic and political interests, and between competing cultural narratives, with the possibility arising of a radical reduction in the proportion of African-American city-dwellers consistent with corporate plans to 'Disneyfy' the city's tourist and conference-going vocation. This threatens to sever the city's unique cultural profile from the vibrant, evolving, popular neighbourhood life from which that culture originally sprang. ${ }^{1}$ A terrain of struggle has for long extended into popular and scholarly historiography, posing the question of how to place - how to assimilate - Louisiana and especially New Orleans into a master national American narrative, and responding with a peripheralisation and exoticisation outside the New England mainspring of 1776 and the manifest destiny of westward expansion. Paradoxically, it is only the recent 'Atlanticisation' of American history, through influential work by, for example, Bernard Bailyn, Peter Linebaugh, Marcus Rediker and John Thornton, ${ }^{2}$ that has permitted Louisiana to find a more rightful place in this narrative, partaking of an interconnected Atlantic history, and even constituting one of its nodal points. ${ }^{3}$

Within French culture, New Orleans and Louisiana have been similarly marginalised, if for different reasons. An emphasis on the overarching centrality of the French national space to the French-speaking world, and an inability to conceive of French culture other than through the expression of a fetishised national language, have meant that Louisiana is often pictured as an exotic remnant of a lost French-speaking world (in representations in popular culture), as part of a French national narrative that stresses rivalry with Britain, the United States and the English language (in much historiography), or, especially from the viewpoint of Quebec, a scarecrow case of the assimilation of French speakers to an overwhelmingly English-speaking continent. In 
France, the 'Atlantic' is still a heavily loaded term with implications of 'Atlanticism' and national defence, and it is still rare for it to be taken as a conceptual space and as the basis for analysis: exceptions are Paul Butel's recent Histoire de l'Atlantique de l'Antiquité à nos jours (Perrin, 1999), and the activities of the Centre de recherches sur l'Histoire du Monde Atlantique at the University of Nantes. Within French and Francophone Studies, Louisiana is still little studied, partly for the reasons just outlined, partly for the unavailability, until recently, of texts from that area written in French. The exception here is of course the work of the pioneering Swiss academic Auguste Viatte, whose Histoire littéraire de l'Amérique française : des origines à 1950 (Paris: PUF, 1954) and later Histoire comparée des littératures francophones (Paris: Nathan, 1980) give the literature of Louisiana a key role.

What follows in this article is an attempt to suggest ways forward for the study and analysis of the culture and history of New Orleans within - or across - disciplines such as French and Francophone Studies, Comparative Literature, and Cultural Studies. Atlantic Studies, it will be argued, is the most effective analytical grid for doing so. 'The French Atlantic' is a de-centred, transnational space of cultural and linguistic transformation, of hybridity, and also of power, domination and resistance. The centrality to it of New Orleans will become clear as soon as we give a historical overview. In addition, the article will examine the abundant literature written there in French during the nineteenth century especially, and then turn to examples of (canonical) French artists working in and representing the city. What must also be emphasised is the mobile, protean nature here of 'Frenchness', which I would define as any cultural form that contains or refers to any narratives, identities and representations of France, the French language, or the wider French-speaking world. This looseness of definition, this minimal particle of meaning, is essential if the interactive and transformative nature of the French Atlantic is to be grasped. The example of jazz is eloquent: amid, as we shall see, the historical 'gumbo' of cultural (and therefore musical) influences present in New Orleans in the late nineteenth century, the answer to that basic Cultural Studies question about the material determinants of cultural forms (why does that particular form emerge there and then?) has to contain crucial French Atlantic elements, including: the specificities of French slave trafficking, ownership, and regulation; the presence of a significant 
population of free people of colour as a direct result of French Atlantic events such as the Haitian Revolution; the resulting rich black cultural and musical life which contained both African and European influences, as in the role of the Paris Conservatoire in training black classical musicians who were then unable to play freely in the segregated cultural life imposed in the postbellum period. And that is not, of course, the end of a French Atlantic story of jazz, since its exportation to France especially after 1917 led to specifically French takes on the phenomenon in both practice (Grappelli, Reinhardt) and theory.

\section{French Rule 1718-1763}

New Orleans under French rule was for the most part a wild and precarious frontier settlement. Its origins, and those of the territory of Louisiana, are inextricably linked to the already established French presence in Canada, or New France, and its lucrative fur trade. René-Robert Cavelier de La Salle (1643-1687), a French adventurer who had settled near Montreal, had been the first European to reach the mouth of the Mississippi, claiming and naming 'Louisiana' - a swathe of territory stretching from the Great Lakes to the Gulf of Mexico and west to the Rockies - for France in 1682. French settlement of the region was subsequently impelled by the issue of the Spanish succession, the war then fought with England and Austria from 1701-1714, and the desire both to protect New France from encirclement and to gain a strategic position in relation to Mexico and its silver mines. The founders of the colony of Louisiana (1699) and then New Orleans (1718) were in fact Canadians: the first governor-general, the French naval officer Pierre le Moyne, sieur d'Iberville (1661-1706) was the son of a Canadian seigneur and had been born and grown up in Montreal; his brother, Jean-Baptiste Le Moyne, sieur de Bienville (1680-1767) lived in Louisiana for 35 years, served four stints as governor until 1743, and is the founder of New Orleans. Half of the population of Louisiana in 1700 was Canadian in origin, and until 1717 the territory was administered as an extension of New France.

This Canadian connection is crucial for understanding the relationship of the colony with native Americans. Unlike the more populous English colonies on the 
Atlantic seaboard, whose agricultural and/or plantation economies were demanding of land, pushing Amerindians to the periphery, New France's wealth, such as it was, was based on the fur trade and in general relationships of cooperation and trade with the natives. The coureurs de bois, whom the French crown vainly hoped would form the basis of a viable Louisiana colony, were those Canadian fur trappers and traders who had 'gone native', expertly adapting themselves to the landscapes and cultures of the North American interior. This distinctive French 'assimilationist' policy with regard to native peoples ${ }^{4}$ should not be mistaken for an idyll. While Bienville was concerned, and had the diplomatic skills, to ally himself with as many native groups as possible, he also played the 'divide and rule' game in maintaining hostilities between his allies the Choctaws and those of the English, the Chickasaws, and used women captured in war by the Choctaws as food-producing slaves. When Bienville was temporarily replaced in 1725 by Etienne de Périer, a company man with no experience of the Americas, encroachments by the colony on land cultivated by the Natchez led in 1725 to a massacre of French settlers and soldiers, followed by even bloodier reprisals which virtually annihilated that particular nation. Nevertheless, it was the natives, and particularly the Choctaws, who saved the colony in its earliest days, as it depended on them to fend off starvation, given the lack of supplies from France and the inhospitable and unfamiliar climate and landscape. Cultural mixing ensued, with many French newcomers temporarily shifted out to native settlements, and intermarriages were frequent, a reality tempered only by Bienville's desire to maintain buffer zones of cohesive native communities in outlying districts well away from New Orleans. This French 'corporatist' policy towards the Amerindians meant that until well into the nineteenth century the city had an Indian market, and people of native descent (mixed with African) were more visible than in any other major American city. ${ }^{5}$

The first African slaves arrived in New Orleans in 1719. From 1712 to 1731, the territory was administered by three private companies, under the French aristocrat, entrepreneur and financial secretary to the king, Antoine Crozat; and the Compagnie d'Occident and Compagnie des Indes run by the Scottish financier John Law, before reverting to crown rule. These speculative and unsuccessful ventures were nonetheless concerned to increase the colony's population, and 7000 settlers were brought in during 
this period. However, they were a motley crew of urbanites, artisans and craftsmen rather than farmers, and many were convicts removed from France by force. In the period until 1731, after which only two shipments arrived under the French regime, 5,500 African slaves were brought into the colony. While a profitable plantation economy failed to take off in this period, the new slave population, who by 1727 constituted $50 \%$ of non-natives, ensured the survival of the colony. The work of Gwendolyn Midlo Hall has demonstrated that, unlike slave populations elsewhere in North America, two-thirds of the slaves imported to Louisiana under French rule came from Senegambia, many from the Bambara ethnic group, and this, plus the chaotic and precarious nature of the colony, "contributed to an unusually cohesive and heavily Africanized slave culture". 6 The slaves contributed agricultural and craft skills which ensured the colony's survival, including rice cultivation and the processing of indigo for dyes. Blacks also played a (limited) military role: for example, fifteen black slaves who fought for the French against the Natchez were freed, forming one of the cores of the city's famous free population of African descent (although many Africans fought on the other side, fomenting rebellion and descent amongst the native groups, and there was a significant population of runaway slaves in the swamps surrounding the city). The French code noir, instigated in 1685 to regulate the treatment of African slaves, was amended for Louisiana in 1724 and 1728, in particular to limit interracial sexual relationships, but this was seldom enforced. Although it would be inappropriate to speak of 'rights' in this context, the Code did stipulate that slave families were to remain intact, and that slaves were able to take Sundays off, a measure which helped the food production of the colony (as some slaves had smallholdings) and enabled many to participate in the city's market economy, as well as to contribute to the development of cultural activities (as, especially in the nineteenth century, in the famous gatherings of slaves and production of music in Congo Square in the city).

By the end of French rule, the population of New Orleans was only 3,190, including 1,288 slaves and 99 free people of colour. And yet a relatively stable, socially stratified, often brutal French colonial society had emerged, its upper echelons represented by the Conseil supérieur - the equivalent of a parlement or ancien régime judicial hereditary caste - and other members of a wealthy elite living off the toil on the 
plantations and, especially after the governorship of the marquis de Vaudreuil (17431753), eager to imitate French fashions and social activities. It was also of course a firmly Catholic (if not particularly religious) city: the 1745-50 Ursulines convent, an entity founded in 1727 , is still the oldest extant in the city.

\section{Spanish rule 1763-1803}

The 1763 Treaty of Paris formalised the loss of most of France's North American territories following her defeat in the Seven Years' War. Eager to retain (SaintDomingue) or regain (Guadeloupe) its wealthy Caribbean possessions, France abandoned its neglected territories: Canada to Britain, and, in a transfer within the Bourbon dynasty, Louisiana to Spain. The first Spanish governor did not arrive until 1766, and was dislodged by a revolt of white creoles (those citizens born in the Americas, mostly of French descent), order being re-imposed only in 1769. However, despite some attempts at imposing the Spanish language, New Orleans, now governed more efficiently and coherently than under the French, remained a French-speaking city, with strong links to France and the francophone world,

Nonetheless, the Spanish period transformed the city in other ways: in architecture, when the city had to be rebuilt after a devastating fire in 1788 (although French-Caribbean influences are also evident in the extant 'French Quarter'), and most notably in terms of population growth. By 1803, the population of Louisiana had increased sixfold, and that of New Orleans threefold. Spain, under the reforming monarch Carlos III, was keen to develop the economy and to attract new settlers. Apart from 2,000 Canary Islanders, these were overwhelmingly French, or Acadian. ${ }^{7}$ The plantation economy developed further, especially at first tobacco, which was given a monopoly in the lucrative Mexican market, and, in the 1790s, cotton (due to technological advances) and sugar (for political and historical reasons to which we shall return). This meant that the Spanish period saw a renewed influx of African slaves.

The Spanish period is also marked of course by the upheavals provoked by the French Revolution and the wars with France that followed. The slave revolt in SaintDomingue in 1791, and the abolition of slavery in the French colonies in 1794, were part 
of a transatlantic movement which led to a distancing from France by slave-owners and merchants, but a widespread political awareness among poor whites as well as blacks: "This internationalist, revolutionary effervescence among the lower classes led by seafarers, the gens de mer, washed up on the shores of Louisiana, radiating to New Orleans and along her major waterways". ${ }^{8}$ In 1795 the Spanish authorities uncovered a planned slave revolt at Pointe Coupée near New Orleans, as a result of which some whites as well as a large number of blacks were punished, and in New Orleans itself many wished for a return to French rule. This came, secretly, in 1800, in the form of the Bonapartist settlement to the events of the 1790s. Napoleon negotiated in the Treaty of San Ildefonso the return to France of what was for Spain a now troublesome territory, but by 1803 , when the French governor (now prefect) took up his post, Napoleon's dream of a new French Caribbean empire had dissolved with the independence of Haiti, for which Louisiana was meant to be the granary. The Purchase agreement, by which the United States paid France $\$ 15$ million dollars for the 827,000 square miles of Louisiana (basically the area between the Mississippi and the Rockies), was signed in Paris in April 1803. A few months later, on 20 December, the American flag flew over the city.

\section{From the Louisiana Purchase to the Civil War 1803-1861}

Paradoxically, in the short to medium term the American takeover inaugurated the most flourishing period of New Orleans' francophone culture, as, despite the influx of American settlers and businessmen, the city remained majority French-speaking for another thirty to forty years. This was because of a large influx of new francophone immigrants. Through gerrymandering, the state remained in Francophone political control until the 1840s, and until 1852 New Orleans was separated into three distinct municipalities, two downtown dominated by French creoles, one uptown by AngloAmericans. The 'foreign French' came from two groups. Migration from metropolitan France, particularly the south and west, brought in 3000 to 7000 people a year from the 1830s, among their ranks a large number of political exiles. Indeed New Orleans was a haven for these: royalists in the 1790s, anti-bonapartists after 1799, bonapartists after 1815 , republicans after 1848 . To these are to be added the large influx from Saint- 
Domingue that began in the 1790s (for example, Louis Guillaume du Bourg, born in Cap Français, was the founder of the city's first newspaper, Le Moniteur de la Louisiane in 1794) and culminated in 1809-10, when Joseph Bonaparte's usurping of the throne of Spain led to war and the expulsion of exiles from Cuba, 10,000 of whom pitched up in New Orleans. These arrivals swelled the ranks of the francophone merchant and professional classes, and contributed much to the cultural dynamism of the following decades, educational attainment and even literacy among the white Creoles being low, despite the ancien régime pretentions of the upper-classes. ${ }^{9}$

The unique character of New Orleans owed much to the significant presence of free people of colour (often but not always lighter-skinned), creating a three-tiered Caribbean-type society at odds with the polarisations of American racism. They represented $29 \%$ of the free population in 1810 (the majority of the city's population were slaves until 1840), although as the city boomed and its population grew this figure had fallen to $6 \%$ by 1860 . Moreover, if most were artisans, many were property-owners (in fact owning $60 \%$ of all the property in the United States owned by AfricanAmericans), and 5\% - a large figure for the time - were professionals. Some were also slave-owners. Their presence, itself a testimony to the relative racial fluidity of the French colonial period, had increased dramatically during Spanish rule, due largely to the greater ease of manumission, and they had even contributed to the defence of the city with their own militia. As American rule meant an institutionalisation of racial exclusions - not least a denial of voting rights, a ban on interracial marriage in 1808, segregation in theatres in 1816 - they often looked to the traditions of enlightenment and republican France for inspiration and support, particularly when slavery was definitively abolished and suffrage extended to black males throughout the French empire in 1848. Their literacy rate of $80 \%$ in 1850 was higher than for Louisiana whites, and as we shall see the assertion of their cultural capital counted for much in an increasingly hostile social environment.

The influx of francophones held off but could not postpone indefinitely the inevitable majority status of the English language and Anglo-American political control, not least as waves of immigration - New Orleans was second only to New York in this 
respect - brought in tens of thousands of Irish and Germans, so that by 1850 almost half of the population had been born outside the Americas.

\section{From the Civil War to Jim Crow 1861-1896}

While their support for the Confederacy was initially at least due to a belief in the possibility of re-establishing a French-dominated Louisiana, the assimilation that followed of the white Creoles to the English language demonstrates the all-pervasiveness of the racial question. The Union army occupied New Orleans in 1862 and for a period closed down the separate French public school system. Creoles were financially ruined by the war and were unable either to send their children to France to be educated or to import French tutors, and after 1865 faced an economic onslaught from northerners. Moreover, the white Creoles had to choose their side in the bitter and violent divide of southern racial/racist politics which marked the period through Reconstruction (when the south was occupied by the Union army and black political rights pushed through), its end in 1877 , and beyond. The choice was to be white above all, and to deny any common ground, let alone ancestry, with the free Creoles of colour:

The white creoles' fervent embrace of the Anglo-Americans' racial mores was doubly ironic. It was ironic, first, as an act of self-denial. Turning their backs on much of their own history, they rejected in the rush to whiteness the historic closeness, indeed interconnectedness, of the white and black creole communities (...) Second, the antebellum ethnic, cultural, and political divisions among whites provided the space within which New Orleans' unique community of free people of color could flourish. The attempt to hijack the creole label for exclusive white use not only furnished evidence of the white creoles' Americanization but also meant that, to the extent New Orleans' creole character survived at all, it did so primarily among nonwhites. ${ }^{10}$

In 186634 Creoles of colour and three whites were killed by a mob that attacked a gathering in the Mechanics' Institute campaigning for universal suffrage. In 1896 the Supreme Court of the United States ruled that the 'Jim Crow' legislation (so-named after a caricatured black character in an old minstrel song) enforcing racial segregation was constitutional, in a case provoked by a free creole of colour and radical political activist, Homer Plessy. It was not until 1978 that Ernest 'Dutch' Morial, the descendant of free 
Creoles of colour from Saint-Domingue, became the first African-American mayor of the city.

I have dwelt on the historical context of the origins of New Orleans, for it is essential for understanding its unique nineteenth-century society, and what is the most tangible legacy for French and Francophone scholars, namely that period's extensive, significant and under-researched literary output.

\section{Literature}

The rhythm and content of francophone literary production in Louisiana mirror these historical upheavals. Although little else emerged during Spanish rule, the inaugural text is an allegorical poem commemorating a Spanish victory over the British, La Prise du morne de Baton Rouge (1779), written by Julien Poydras (1740-1824), a native of Nantes who became a wealthy planter and philanthropist, and from whose plantation the 1795 Pointe Coupée slave rebellion emanated. According to James Cowan, a 'salon comedy' by Félix Voorhies, Les Noces d'argent du couple Néral (1918) closes the period, ${ }^{11}$ just three years before a legislative decision to ban the speaking of French in state schools effectively put paid to francophone Louisiana literature for the next fifty years. Within that period, an apogee of production was reached between 1840 and 1860, but significant works continued to be produced until the end of the century, thanks to the rearguard francophone activity of the Athénée louisianais, and its regular Comptes-rendus, founded in 1876 by Alfred Mercier (1816-1894), a white Creole who had trained as a doctor in Paris, indeed practising medicine there during the Civil War.

Mercier's transatlantic passages, in the literal and figural senses, are typical of this literature. The Creole community had close links with France, and much of the inspiration for and style of nineteenth-century Louisiana literature bear the hallmark of contemporary French output. Indeed, some of the writers were themselves French immigrants, such as Alexandre Barde (1816-1868), whose Mademoiselle de Montblancard (1843) is claimed by Viatte to be the first 'Louisiana novel', although it is set in the author's native Languedoc. (In fact, it is more of an extended novella, appearing in serial form in the newspaper Le Courrier de la Louisiane, this form of publication 
being the main outlet for writers, given the paucity of publishing houses and the restricted reader base; 135 newspapers came and went in New Orleans in the nineteenth century.) In addition, much Louisiana writing was inspired by Parisian developments, such as takes on Eugène Sue: Les Mystères des bords du Mississippi (1843-4) by Charles de la Gracerie and Or et fange ou les mystères de la Nouvelle-Orléans (1852-3) by the French émigré Charles Testut (1818-1892). However, the main influences were Romanticism and melodrama, as most literary output took the form of poetry and drama, audiences flocking to the two francophone theatres in the city, the Théâtre d'Orléans and the Théâtre Saint-Charles, and tropes from both these genres played a major role in prose fiction.

It would be inappropriate, however, to see here merely a slavish following of Parisian fashion. The massive presence of writers such as Hugo and Lamartine, as well as the highly popular Béranger, could be put to different uses for different aesthetic and political projects. Rather, Louisiana literature in its diversity can be read as a tension between forces - of mimicry and authenticity, and of the transatlantic and the local negotiating through Romanticism particular articulations of the personal and collective via, for example, tropes of emotional loss that spoke to the historical itinerary of the Creole people. The Louisiana landscape, but also its historical narratives, play major roles in constructing this collective identity, as in the memory of the French Creoles who had rebelled against Spanish rule: Alfred Lussan's 1839 play Les Martyrs de la Louisiane, or France et Espagne, ou la Louisiane en 1768 et 1769 (1850), by the Creole of colour Placide Canonge (1822-1893), which anachronistically portrays a modernising movement for independence inspired by Enlightenment values, much more of a comment on the anteum 1850s than on the eighteenth century. The revolt is also the subject of the novel Louisiana (1849) by émigré French writer Armand Garreau (1817-1865). Charles Testut wrote a historical novel, Saint-Denis (1849), on the life of the frontiersman Louis Juchereau de Saint-Denis (1684-1744). Here and elsewhere the contribution of native peoples to the life of Louisiana underlines the specificity of the territory: the first play written in Louisiana was Paul Louis Le Blanc de Villeneuve's L'Héroisme de PouchaHoumma $^{12}$ (staged 1809, published 1814), nostalgic for the old days of FrancoAmerindian relations. La Nouvelle Atala (1879), a novel by Adrien Rouquette (1813- 
1887), who took orders and went to live as a priest with the Choctaws, is a spiritual work which suggests links between natives, Creoles and landscape in its critique of modernity and capitalism. The suggestion is that this 'new Atala' is a more authentic version of the creation of Chateaubriand, who relied on travel accounts for his description of the Mississippi. Rouquette's brother, Dominique (1810-1890) had in fact admonished Chateaubriand in this way in his 1836 poem 'Exil et patrie': "Loin du boueux Paris, viens poète avec nous!/Européen blasé, viens te faire sauvage". ${ }^{13}$ Both the Rouquette brothers are strong on combining French Romantic tropes with the realist details of New Orleans

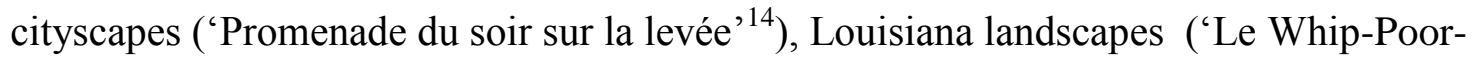
Will'15), and the Atlantic itself ('Rêve de départ en Bretagne et en Normandie' ${ }^{\text {,6). }}$

The other most significant poets of the corpus are: Alexandre Latil (1816-1851), author of Les Ephémères (1841), heavily influenced by Romanticism, and who suffered from leprosy most of his adult life; Tullius Saint-Céran (1800-1855), the son of French planters on Jamaica who fled an insurrection and settled in New Orleans, and who is a good if bombastic example of the conjunction of Romanticism and republicanism, and of the transatlantic (a hyperbolic couplet on Béranger ${ }^{17}$ ) and the local (1814 et 1815 ou les combats et la victoire des fils de la Louisiane, an epic poem published in 1838 on the battle of New Orleans against the British); and Georges Dessommes (1855-1929), whose 'Un Soir au Jackson Square' (1880) combines the eyes of the urban flâneur with social realism (the 'nègre', the street urchins, the milling workers) and an awareness of collective destiny and loss, namely the 'vieux Français' "Heureux de retrouver vaguement la patrie/Dans ces illusions d'un lointain souvenir". ${ }^{18}$ Jackson Square is of course the former French Place d'Armes at the heart of the old colonial city.

Dessommes is also the author of a novel, Tante Cydette (1888), which allegorises the relationship between white Creoles, France and the United States via a heterosexual romance, in which the heroine, 'Louise', renounces a union with a wealthy Frenchman. The three most important novels in the corpus were all published during this postbellum period, and this new openness is partly due to the fact that the question of slavery had at least been settled, even if institutionalised racism had continued. In the antebellum climate, an 1830 law against encouraging slave rebellion, and which even prohibited fomenting discontent among free people of colour, led to a degree of self-censorship 
among writers. Charles Testut's abolitionist novel, Le Vieux Salomon, was written in 1858 but not published until 1872. As Sheri Abel and Heidi Kathleen Kim have pointed out, the novel side-steps the anglophone American sentimentalist tradition, drawing on French socialism, freemasonry, and Testut's interest in spiritualism (shared with many of these writers) to construct a truly Atlantic as opposed to national vision of the (now illegal) slave trade, with its scenes in Guadeloupe, Louisiana, Alabama, on ships, and briefly in New York. ${ }^{19}$ Beginning with a young Frenchman stepping off his ship in New Orleans and witnessing a slave auction, Alfred Mercier's antislavery L'Habitation SaintYbars (1881) is remarkable for its extensive use of the creole language (which had developed out of the Franco-African interactions in Louisiana and the West Indies in the eighteenth century, later supplemented by further interactions with Cajuns and also transplanted Saint-Domingue slaves). ${ }^{20}$ Mercier also wrote a novel about abortion, Johnelle (1891). The most prominent woman writer of this period, Sidonie de La Houssaye (1820-1894), also had an extensive output, writing a version of the Acadian Evangeline myth, Pouponne et Balthazar (1888), and most importantly an examination of the fate of the 'quadroons', mixed-race women who earlier in the century would be 'placed' as official mistresses to married white men: Les Quarteronnes de la NouvelleOrléans (published in serial form, 1894-8). ${ }^{21}$

For writers who were free Creoles of colour, the pressures of self-censorship, but also the urgent necessity to make connections between poetry and politics, just as Hugo and Lamartine had done in France, ${ }^{22}$ were intensified. The poetry anthology Les Cenelles: choix de poésies indigènes (1845, named after a local fruit) was the first such collection by African Americans. ${ }^{23}$ It was edited by Armand Lanusse (1812-1867), who had been educated at the Ecole Polytechnique in Paris, and who in 1843 had created a literary journal, L'Album littéraire, to publish work by Creoles of colour (although it was also open to whites). Although the collection is diverse and the project mainly concerned to demonstrate the cultural legitimacy, in Pierre Bourdieu's sense, of the community from which it had sprung, it does include for example 'Epigramme', a stinging piece by Lanusse on the practice of plaçage. This was also the preoccupation of his 1843 short story Un Mariage de conscience, ${ }^{24}$ in which the emotional intensity and moral polarisations of melodrama - which traditionally "deals in conditions of personal guilt 
and innocence which can be established in relation to any discourse that demarcates the desirable from the taboo" 25 - is here played out on the terrain of racial politics. This is also the strategy of, for example, Adolphe Duhart (1830 -1909) in the short stories Simple Histoire (1865, a love story between a slave and his mistress) and Trois Amours (also 1865 , in which a young white Creole man falls in love with a young woman whose secret is her coloured status). Another strategy was to set such intrigues outside the United States, and, in the case of Victor Séjour (1817-1874), to publish abroad. His violent short story Le Mulâtre (1837), the first by an African American, was published in Paris in the abolitionist Revue des colonies. Set in pre-revolutionary Saint-Domingue, from which Séjour's own father hailed, it recounts the revenge of mixed-race slave Georges, whose wife refuses the slave master's advances, accidentally striking him and thus condemning herself to death; the master refuses to spare her, and he and his family are killed by Georges, just as the latter learns that the master is in fact his biological father. Séjour left New Orleans at the age of nineteen and settled in Paris for the rest of his life, becoming a convinced bonapartist and a successful playwright, making him the most prominent of all the Creole writers of colour and the first African American to have his works published commercially. He took as his role model, and cultivated a friendship with, Alexandre Dumas, that other Creole of saint-dominguais descent. Séjour's writings, often grandiose historical epics seemingly worlds apart from Louisiana, nonetheless often return to the subject of discrimination, in the form of judeophobia/antisemitism: Diégarias (1844), La Tireuse de cartes (1859). The manuscript of a play entitled L'Esclave, completed just before his death, has been lost. ${ }^{26}$

Other Creole writers of note include: Michel Séligny (1806-1867), whose short story Souvenirs de 1815 (1839) very obliquely, and in melancholic fashion, recalls the contribution made by the now outlawed coloured militia to the defence of the city; ${ }^{27}$ Camille Naudin, whose poem 'La Marseillaise noire' of 1867 is inspired by French republican traditions and the example of Lamartine; and Joanni Questy (1818-1869), in whose story Monsieur Paul (1867) a coloured Creole narrator and an old French émigré discover a shared culture beyond the racial divide, including values of honour that come into play when the Frenchman is mortally wounded by the American who has replaced him in the affections of his Creole lover. By 1867, despite the fraternal hopes expressed 
in 'La Marseillaise noire', the possibility of white Creoles and Creoles of colour coming together around a common project was fading. (In 1861, when the secession of the South seemed to suggest that Louisiana could reconnect with its French past, writers and intellectuals across the racial divide, including Duhart and Séligny - who later fled to Paris - gathered round a weekly review, La Renaissance louisianaise, and there was a last-ditch attempt to ally white businessmen and well-to-do coloureds in the Unification movement of 1873.) In the 1860s, specifically coloured newspapers - L'Union and La Tribune - were formed, the latter being the forum for 'La Marseillaise noire'. Monsieur Paul continues the thread of loss and valediction to a disappearing world that runs through much of Louisiana's creole literature.

\section{Representations}

The end of the francophone literature of New Orleans at the start of the twentieth century is just one event in the long history of French Atlantic interactions, including the representations made of the city by French artists, writers and filmmakers. Louisiana in recent years has been the setting of door-stopping best-selling historical novels by Maurice Denuzière (Louisiane, 1977; Je te nomme Louisiane, 1990), as well as by the Ecole de Brive 'regionalist' writer Michel Peyramaure (Louisiana, 1996). Jackie Landreaux-Valabrègue, of Louisiana descent but resident in France, has written a children's book based on the life of Adrien Rouquette with the Choctaws: Chahta-Ima la voix des Indiens (1999). In many of these texts, the emphasis is not on the racial and sexual complexities of New Orleans but on either plantation life or the 'virginal' American forest, drawing on the tradition of Chateaubriand: this is even the case of the Godard-Ribera bande dessinée Le Grand Scandale (1997), volume four of which, 'New Orleans', places its present-day American hero Al Jackson briefly in the Vieux Carré, but these scenes are dominated by a generic alleyway fight and a bar frequented by Houma Indians, one of whom he had rescued in the swamps.

By far the most famous representation of New Orleans in French literature is the canonical Manon Lescaut (1731), in which the abbé Prévost portrays the territory in terms of deserts rather than swamps. However, this is appropriate in terms both of the 
bleak reality of the colony in relation to official propaganda, and of the moral and emotional wasteland in which Manon's death takes place. Manon is the victim of the sexual brutality of the colony, in which the fate of unmarried female migrants - be they deportees (200 women were thus transported in the Regency period, mostly from the Salpêtrière prison where they had been confined for begging, prostitution, vagabondage, and other petty crimes) or filles à la cassette bearing a royal dowry (120 in 1719-20) was in the hands of the governor. Manon/Manon also inaugurates a tradition of feminising and sexualising the city of New Orleans which has since taken many forms, bearing, since the founding of the Ursulines convent, the deep structure of nun/prostitute, and continuing through the city's port culture, the legendary quadroon balls, and the setting up of the Storyville district, within which from 1897 to 1917 prostitution and brothels were legalised, and which was one of the seedbeds of jazz:

Cities like Paris and New Orleans that are feminized and associated in popular memory with consumption rather than production, pleasure rather than labor, offer multiple opportunities for artists to explore contradictions, secrets, the sexually and racially exotic and gothic - especially when populist discourses can present such cities too easily as outside history, associated with the consuming pleasures of the female body. ${ }^{28}$

Storyville is the setting of Louis Malle's 1978 film, Pretty Baby. As Joseph Roach has argued, the 'virginity auction' which takes place in that film, along with other performances or 'circuses' regularly put on by the brothels, insisted "on constructing the linkages between the diverse flesh markets throughout the circum-Atlantic world". ${ }^{29}$ A femme fatale in the form of an American feminist academic is at the heart of a curious fiction by the psychoanalyst Gérard Pommier, $<<$ Ceci n'est pas un pape $>>$ : Inconscient et culture en Louisiane (1996), which, like Eco's The Name of the Rose, combines philosophical discussion and policier intrigue. Using a Freudo-Lacanian framework, a Parisian psychoanalyst, Jean Quenais, visits New Orleans to investigate the 'collective fictions' via which cultures are unconsciously transmitted, as in the Catholic/Protestant division played out in the city and its effect on race relations.

The most significant French artistic encounter with New Orleans was the visit by Edgar Degas in 1872-3, the only example of an Impressionist painter working in the United States. For Degas, the visit was a family affair, a stay with his maternal uncle 
Michel Musson and his cousins: his mother, Célestine Musson, who had died in Paris in 1847, was the daughter of a refugee from Saint-Domingue who made a fortune in cotton in New Orleans. Edgar Degas's brothers René and Achille had moved to New Orleans in 1870 to work in the family cotton business. The family of Degas's great-grandfather Vincent Rillieux were also related to the city's community of free Creoles of colour through his son Vincent junior's liaison with a coloured mistress, Constance Vivant. Degas's main works from his five-month New Orleans stay, apart from family portraits, are Children on a Doorstep (New Orleans), which is the only one to represent a black personage, the children's nurse, and A Cotton Office in New Orleans (figure 1), a portrait of the offices of the Musson family firm and "one of the great depictions of modern business life". ${ }^{30}$ The dislocating angles, thresholds, and frames-within-frames of the painting speak to Tocquevillean ambivalences about American business and the relations between social order and isolated, autonomous gestures, human details and commercial exchange, the private and the public. This is both a family portrait (Michel Musson in the foreground is checking the quality of the cotton, Degas's brother René is reading the newspaper, Achille is leaning against the left window like a flâneur) and a picture of abstract, separate activities rather than shared, direct relations. Dominating the scene, at the centre of a play of blacks and whites in the men's dress, and the newspaper, is the cotton itself, implying by its very presence the "absent black labour". ${ }^{31}$ In fact, the painting portrays a world that is fast disappearing: the Musson firm went bust in February 1873 at a time of economic crisis; cotton factors, the planters' intermediaries which were were often small family firms like the Mussons', were now being replaced by cotton exchanges linked by telegraph; and the racial and economic authority of these white men was being questioned during the Reconstruction period, so that Michel Musson, after the failure of the Unification project, became one of the leaders of the Crescent White League, a supremacist movement that emerged once it became clear that white and coloured creoles had no future together. Musson is a good example of the fluid, opportunist, business orientation of certain white Creoles, choosing to live in the 'American' Garden District rather than the Vieux Carré (before financial difficulties forced the family to move to a rented house on Esplanade), and ready when appropriate to sign his name 'Michael'. 
The uncertain future of New Orleans alluded to at the beginning of this article implies a whole series of geographical interrogations of space and time in the city. The accusation - or threat - of 'Disneyland' has a tendency to put a stop to analysis and debate when in fact it is a starting-point. What notions of authenticity are thereby articulated, and how are they grounded? What meanings - for which publics - are contained in the 'Frenchness' marketed to the city's 10 million tourist visitors in 2004, in terms of heritage and the preserved past? What (identity) narratives are mobilised for what inclusions and exclusions? It is significant that one of the most sustained recent treatments of these questions in the field of cultural geography has been one consistent with Atlantic Studies, a comparison of the two founding French settlements at opposite ends of North America, Quebec City along with New Orleans, in Martine Geronimi's Québec et la Nouvelle-Orléans: paysages imaginaires français en Amérique du nord ${ }^{32}$. Among the experiences that tourists seek and find in these sites is a complex passage through familiarity and difference, Frenchness and Americanness, an 'elsewhere' (and Foucault's notion of heterotopia is here compelling) whose identity is central (to a whole narrative of the French in North America) and dense (in their distinct urban topographies), but also liminal and marginal, hence Geronimi's emphasis on the 'imaginary'. The shifting, mobile historical realities of Frenchness in New Orleans, the hybrid French Atlantic space par excellence, demand attention.

\footnotetext{
${ }^{1}$ See for example: M.Davis, “A la Nouvelle-Orléans, un capitalisme de catastrophe”, Le Monde diplomatique (October 2005), pp. 1, 4-5; N.Cohn, "The Day the Music Died", The Observer Review, 15 January 2006, pp. 4-6.

2 B.Bailyn, "The Idea of Atlantic History", Itinerario, 20 (1996), 18-44, and Voyagers to the West: A Passage in the Peopling of America on the Eve of the Revolution (New York: Random House, 1988); P.Linebaugh and M.Rediker, The Many-Headed Hydra: The Hidden History of the Revolutionary Atlantic (London: Verso, 2002); J.Thornton, Africa and Africans in the Making of the Atlantic World 1400-1800 (Cambridge University Press, 1998).

${ }^{3}$ For example: B.G.Bond (ed), French Colonial Louisiana and the Atlantic World (Baton Rouge: Louisiana State University Press, 2005); G.M.Hall, Africans in Colonial Louisiana: The Development of Afro-Creole Culture in the Eighteenth Century (Baton Rouge: Louisiana State University Press, 1992).
} 


\footnotetext{
${ }^{4}$ Jerah Johnson has argued for the profound origins of this policy in ancien régime France: "Colonial New Orleans", in A.R.Hirsch and J.Logsdon (eds), Creole New Orleans: Race and Americanization (Baton Rouge: Louisiana State University Press, 1992), pp. 12-57.

${ }^{5}$ Ibid., pp. 39-40.

${ }^{6}$ Ibid., "The Formation of Afro-Creole Culture", p. 65. See also: I.Seck, "The Relationships between St.Louis of Senegal, its Hinterlands, and Colonial Louisiana", in Bond, op.cit, pp. 265-290.

${ }^{7}$ The dispersal by the British of the Acadiens from what is present-day Nova Scotia had begun in 1755, with the first arriving in Louisiana in 1764, after which Spanish governors actively encouraged them to settle, a process which continued until 1785. As most Acadians settled as farmers in rural (pasture or swamp) areas, they mainly fall outside a study of the city of New Orleans, although they helped perpetuate the French character of Louisiana under American rule, and in 2006 constitute most of the $6 \%$ of the state's population who are French-speaking, concentrated around Lafayette. For more on their history, including their complex relations with the Creoles who saw them as peasants and themselves as aristocrats, see the comprehensive historical work of Carl A. Brasseaux: "Scattered to the Wind": Dispersal and Wanderings of the Acadians 1755-1809 (Center for Louisiana Studies: University of Southwest Louisiana, 1991); The Founding of New Acadia: The Beginnings of Acadian Life in Louisiana, 1765-1803 (Baton Rouge: Louisiana State University Press, 1987); Acadian to Cajun: Transformation of a People, 1803-1877 (Jackson: University Press of Mississippi, 1992). Cajun cultural traditions have been mainly oral, musical, and culinary, but the creation in 1968 by the state legislature of CODIFIL, the Council for the Development of French in Louisiana, led to a literary renaissance in the late 1970s, particularly in poetry and theatre.

${ }^{8}$ Hall (1992), p. 347.

${ }^{9}$ For more on the influence of the Saint-Dominguais and of the events in Haiti, see: A.N.Hunt, Haiti's Influence on Antebellum America: Slumbering Volcano in the Caribbean (Baton Rouge: Louisiana State University Press, 1988).

${ }^{10}$ Hirsch and Logsdon, op.cit., p. 98.

${ }^{11}$ J.L.Cowan (ed), La Marseillaise noire et autres poèmes de la Nouvelle-Orléans (Lyon: Cosmogone, 2001), pp. 38-40.

${ }^{12}$ Available online at: http://www.centenary.edu/french/houmma/ as part of the project at Centenary College Shreveport to rediscover and republish, through its Editions Tintamarre, this literary corpus. Other texts mentioned in this article are also available at their site.

${ }^{13}$ Les Méschacébéennes (Paris: Sauvaignat, 1839).

${ }^{14}$ From Adrien's 1841 collection, published in Paris, Les Savanes, republished in Creole Echoes: The Francophone Poetry of Nineteenth-Century Louisiana, translated by N.R.Shapiro, introduction and notes by M.L.Weiss (Urbana: University of Illinois Press, 2004), pp. 158-60.

${ }^{15}$ Ibid., p. 172, from Dominique's 1856 collection, Fleurs d'amérique.

${ }^{16}$ Fleurs d'amérique (New Orleans: H.Méridier, 1856).

${ }^{17}$ Creole Echoes, op.cit., p. 188.

${ }^{18}$ Ibid., pp. 52-4.

${ }^{19}$ S.Abel, "'The Stupid Aristocracy of Skin': Charles Testut's French Southern Antislavery Novel Le Vieux Salomon, ou une famille d'esclaves au xixième siècle", unpublished MA dissertation, Tulane University, 2003; H.K.Kim, "Resistance in French: Recentering the World of Slavery in Charles Testut's Le Vieux Salomon", paper given at Southern American Studies Association, Louisiana State University, Baton Rouge, February 2005.

${ }^{20}$ See: L.Rosenwald, “Alfred Mercier's Polyglot Plantation Novel of Louisiana”, in M.Shell, American Babel: Literatures of the United States from Abnaki to Zuni (Cambridge, MA: Harvard University Press, 2002), pp. 219-237; S.D.Dickinson, "Creole Patois in the Novels of Dr Alfred Mercier", Louisiana Literature, 8, no. 1 (Spring 1991), 69-80.

${ }^{21}$ See J.J.Perret, "S. de la Houssaye's Quadroon Tetralogy: 'Les Quarteronnes de la Nouvelle-Orléans"', Louisiana Literature, 11, no. 2 (Fall 1994), 12-44.

${ }^{22}$ C.C.Bell, Revolution, Romanticism and the Afro-Creole Protest Tradition in Louisiana, 1718-1868 (Baton Rouge: Louisiana State University Press, 1997).

${ }^{23}$ Two of its poems were anthologised by the Harlem Renaissance poet Langston Hughes: The Langston Hughes Reader (New York: George Braziller, 1958).

${ }^{24}$ This and the other stories cited in this and the next two paragraphs are published in C.Michaelides (ed), Paroles d'honneur: Ecrits de couleur néo-orléanais 1837-1872 (Shreveport: Editions Tintamarre, 2004).
} 
${ }^{25}$ C.Gledhill (ed), Home Is Where The Heart Is: Studies in Melodrama and the Woman's Film (London: British Film Institute, 1987), p. 32.

${ }^{26}$ C.E.O'Neill, Séjour: Parisian Playwright from Louisiana (Lafayette: Center for Louisiana Studies, 1995), p. 133.

${ }^{27}$ Texts by Séligny are collected in: F. C. Amelinckx (ed), Michel Séligny: homme libre de couleur de la Nouvelle-Orléans (Sainte-Foy: Presses de l’Université Laval, 1998).

${ }^{28}$ H.Taylor, "New Orleans", in B.Marshall (ed), France and the Americas: Culture, Politics and History (Santa Barbara \& Oxford: ABC-Clio, 2005), pp. 866-872.

${ }^{29}$ J.Roach, Cities of the Dead: Circum-Atlantic Performance (New York: Columbia University Press, 1996), p. 227. Roach makes the same reading of Manet's Olympia (1863).

${ }^{30}$ C.Benfey, Degas in New Orleans: Encounters in the Creole World of Kate Chopin and George Washington Cable (Berkeley: University of California Press, 1997), p. 164.

${ }^{31}$ M.R.Brown, Degas and the Business of Art: A Cotton Office in New Orleans (University Park: Pennsylvania State University Press, 1994), p. 42.

${ }^{32}$ (Paris: Belin, 2003). 